\title{
Time Interval Between Cover Crop Termination and Planting Influences Corn Seedling Disease, Plant Growth, and Yield
}

J. Acharya, Department of Plant Pathology and Microbiology, Iowa State University, Ames 50011; M. G. Bakker, T. B. Moorman, and T. C. Kaspar, National Laboratory for Agriculture and the Environment, United States Department of Agriculture-Agricultural Research Service, Ames, IA 50011; A. W. Lenssen, Department of Agronomy, Iowa State University, Ames; and A. E. Robertson, Department of Plant Pathology and Microbiology, Iowa State University, Ames

\begin{abstract}
Experiments were established in a controlled-growth chamber and in the field to evaluate the effect of the length of time intervals between winter rye cover crop termination and corn planting on corn seedling disease, corn growth, and grain yield in 2014 and 2015. Rye termination dates ranged from 25 days before planting (DBP) to 2 days after planting (DAP) corn in the field and from 21 DBP to 1 DAP in controlled studies. Results were similar in both environments. In general, shorter intervals increased seedling disease and reduced corn emergence, shoot growth, and grain yield of corn following winter rye compared with corn planted

10 or more days after rye termination or without rye. Incidence of Pythium spp. increased with shorter intervals (less than 8 DBP); incidence of Fusarium spp. was not consistent between runs and experiments. In 2014, in the 1-DAP treatment, number of ears and grain yield were reduced $(P=0.05$ and 0.02 , respectively). In 2015 , all termination intervals reduced plant population, number of ears, and yield $(P=$ 0.01 ), with the 2-DBP treatment causing the biggest decrease. A 10- to 14-day interval between rye termination and corn planting should be followed to improve corn yield following a rye cover crop.
\end{abstract}

Cropping systems in the upper Midwest of the United States are dominated by corn (Zea mays L.) and soybean (Glycine max L.) rotation, and numerous studies have shown that a significant proportion of the nitrate found in Midwest surface waters originates from these corn and soybean fields (David et al. 1997; Dinnes et al. 2002). One approach to reducing nitrate losses from the corn-soybean rotation is to plant cover crops. Cover crops grown between crop maturity in the fall and planting of a subsequent corn or soybean crop in the spring can improve soil and water quality by increasing soil organic matter, recycling nutrients, reducing nitrogen $(\mathrm{N})$ and phosphorus losses in surface runoff and tile drainage, and inhibiting weed growth (Basche et al. 2016; Kaspar et al. 2007, 2012; Moore et al. 2014; Reddy et al. 2003; Snapp et al. 2005; Teasdale 1996; Varco et al. 1999). Many plant species are used as cover crops, and the species selected often depends on the cash crop rotation, the period of the year between main crops, the climate conditions of the area, and the potential growth of the cover crop. In the upper Midwest, cool-season grass cover crops such as oat (Avena sativa L.), winter wheat (Triticum aestivum L.), and winter rye (Secale cereale L.) are often planted in corn-soybean cropping systems (Singer et al. 2007; Snapp et al. 2005). Among these species, rye is well suited to Iowa because of its ability to survive Iowa's minimum winter temperatures, grow relatively fast at cool temperatures, and produce a substantial amount of biomass before spring planting of the cash crop (Snapp et al. 2005).

Despite the numerous environmental and soil benefits associated with cover crops, their use has not been widely adopted in Iowa. Between 2001 and 2005, only $11 \%$ of farmers had tried a cover crop on

Present affiliation of M. G. Bakker: Mycotoxin Prevention and Applied Microbiology, USDA-ARS, Peoria, IL.

Corresponding authors: A. E. Robertson; E-mail: alisonr@iastate.edu; and T. C. Kaspar; E-mail: Tom.kaspar@ars.usda.gov

Mention of trade names or commercial products in this publication is solely for the purpose of providing specific information and does not imply recommendation or endorsement by the U.S. Department of Agriculture. USDA is an equal opportunity provider and employer.

Accepted for publication 23 November 2016.

C 2017 The American Phytopathological Society their farms (Singer et al. 2007). A later survey (NASS 2014) reported that cover crops had been planted on only $1.6 \%$ of the harvested corn and soybean acres in Iowa. One possible reason for the low adoption rate may be reports of occasional yield losses in corn following rye (Dinnes et al. 2002; Johnson et al. 1998; Kaspar and Bakker 2015; Pantoja et al. 2015). This possible yield reduction, in addition to the cost and labor required to grow cover crops, has led to reluctance among farmers to try rye cover crops in their cropping system (Arbuckle and Roesch-McNally 2015). Thus, understanding how rye negatively affects corn yield and developing management practices to eliminate this risk is important for farmer adoption and to achieve the full potential of the environmental and soil health benefits of cover crop use.

Several possible reasons have been suggested for the reported reduction in corn yield following rye cover crops. These include reduced inorganic $\mathrm{N}$ and water availability due to cover crop uptake, inhibitory allelochemicals from living or dying rye plants, immobilization of $\mathrm{N}$ during decomposition of the cover crop, poor planter performance related to planting into dense plant residue and near-surface roots, and increased pest pressure (Duiker and Curran 2005; Ebelhar et al. 1984; Karlen and Doran 1991; Kessavalou and Walters 1997; Mitchell and Tell 1977; Tollenaar et al. 1993; Wagger and Mengel 1993).

Another possibility for reduced yield that has received less attention is that a cover crop may increase the risk of seedling disease in the following crop, leading to reduced plant population and yield. Cover crops may act as a "green bridge" or living host for plant pathogens (Smiley et al. 1992), allowing pathogens to maintain or increase their population size during the normally fallow period between the harvest of one crop and the emergence of a new crop, when their densities would typically be expected to decline. For example, Rothrock and Kirkpatrick (1995) recovered Rhizoctonia solani (Kühn) from cotton seedlings following a hairy vetch (Vicia villosa L.) cover crop more frequently than from cotton seedlings following a winter fallow. They also observed reduced cotton stands due to cotton seedling disease caused by $R$. solani following a hairy vetch cover crop. Recently, Bakker et al. (2016) demonstrated that rye cover crops host corn seedling pathogens. They showed that isolates of Pythium sylvaticum (W. A. Campb. \& F. F. Hendrix), P. torulosum Coker \& P. Patt, Fusarium graminearum (Schwabe), and F. oxysporum (Schltdl.) that were recovered from rye roots in the field were capable of causing seedling disease of corn in controlled-environment studies. 
These four species also had been previously identified as causing seedling disease of corn in fields without cover crops (Matthiesen et al. 2016; Munkvold and O'Mara 2002). Thus, we suggest that a rye cover crop may serve as a green bridge for corn pathogens, and that emerging corn seedlings following a rye cover crop may be exposed to higherthan-normal pathogen inoculum densities. As a result, there is an increased risk of seedling disease, stand loss, reduced vigor, and, in some cases, reduced corn yield following winter cereal cover crops.

One management practice that appears to reduce the risk of a corn grain yield reduction following a rye cover crop is killing the cover crop 2 to 3 weeks before corn planting (Ball Coelho et al. 2005; Munawar et al. 1990; Raimbult et al. 1991). Munawar et al. (1990) attributed the greater corn yield following rye killed 2 to 3 weeks before planting to greater soil water availability. Raimbult et al. (1991) speculated that the decreased corn yield when corn was seeded immediately after rye kill was due to a combination of greater amounts of rye residue, less water availability, or the phytotoxic effects of allelochemicals that were produced during decomposition of rye residues. Ball Coelho et al. (2005) reported that a rye cover crop killed 2 weeks before planting allowed more time for decomposition and more timely release of cover crop N.

Although not mentioned by these authors, the time interval between termination of the cover crop and planting of the conventional crop may also affect the risk of seedling diseases and yield reductions by pathogens. For instance, Smiley et al. (1992) reported greater Rhizoctonia root rot in spring barley (Hordeum vulgare L.) planted soon after terminating volunteer winter wheat with glyphosate than in barley planted 22 days after termination of wheat. They hypothesized that a longer time interval between termination of volunteer wheat and planting of a spring barley crop allowed less wheat growth, which reduced the mass of wheat roots serving as a food base for soilborne pathogens and allowed more time for competing soil microorganisms to reduce pathogen inoculum levels in the dead wheat roots. Similarly, Sharma-Poudyal et al. (2016) found that increasing the time interval between herbicide application to a wheat cover crop and onion planting reduced the infection of onion roots by Rhizoctonia spp. Finally, Dabney et al. (1996) reported that sorghum root disease incidence decreased when the time interval between spraying legume cover crops and planting sorghum was increased. These studies suggest that the time interval between termination of rye cover crops and corn planting may also be important. We hypothesize that the risk of corn seedling disease following rye would decrease as the termination-time interval increases and, consequently, the risk of corn yield reductions would increase with short termination-time intervals.

In an effort to improve management of cover crops and to understand the impact of rye cover crops on corn seedling diseases, we performed growth-chamber and field studies to evaluate the effect of termination-time interval on seedling disease, plant growth, and yield of corn.

\section{Materials and Methods}

Controlled-environment experiment. Field soil, a Webster silty clay loam (fine loamy, mixed, superactive, mesic Typic Endoaquolls), was collected from a continuous corn field in fall 2013. The soil was sieved through 4- and 2-mm sieves and used to fill 0.5 -liter polystyrene cups. Five rye seeds ('Elbon') were planted in each cup. Cups not planted to rye were included as a check. All cups were placed in a growth chamber at $20^{\circ} \mathrm{C}$ with $16 \mathrm{~h}$ of light and $10^{\circ} \mathrm{C}$ with $8 \mathrm{~h}$ of darkness. After 4 weeks, the rye plants in all cups were terminated by spraying with glyphosate ( $N$-[phosphonomethyl] glycine; active ingredient [a.i.] at $6.6 \mathrm{~g} /$ liter) with a pump spray bottle to result in an application rate approximately the same as in the field experiment. All cups without rye were also sprayed with glyphosate. Fungicide-treated corn seed (Hybrid P1151R; DuPont-Pioneer Hybrid International) were sown into the cups ( 5 seeds/cup) at six time intervals relative to the application of herbicide to the rye ( 1 day before or $3,7,10,14$, or 21 days after rye termination). The corn seed was treated with metalaxyl (Alliance; Bayer CropScience, $291 \mu \mathrm{l}$ a.i./kg), pyraclostrobin (Stamina; BASF, $467 \mu \mathrm{l}$ a.i./kg), fludioxonil
(Maxim 4FS; Sygenta, $95 \mathrm{ml}$ a.i./kg), ipconazole (Rancona; Valent, $30 \mu \mathrm{l}$ a.i./kg), and sedaxane (Vibrance 500; Sygenta, $189 \mathrm{ml}$ a.i. $/ \mathrm{kg}$ ). After corn planting, the cups were placed in the growth chamber at $12^{\circ} \mathrm{C}$ with $16 \mathrm{~h}$ of light and $10^{\circ} \mathrm{C}$ with $8 \mathrm{~h}$ of darkness for 32 days. Plants were watered ( 50 to $60 \mathrm{ml}$ ) every 2 to 3 days and nutrient solution (Miracle-Gro; $2.22 \mathrm{mg} /$ liter of water; Scotts Miracle-Gro Products) was applied once a week. Treatments were arranged in a randomized complete block design. There were four cups or replications per treatment. The growth-chamber experiment was conducted two times.

Corn seedling growth and disease assessment. Corn seedlings were harvested 32 days after planting and carefully washed under running water to remove adhering soil. Seedling growth parameters (emergence, shoot height, shoot dry weight, and radicle length) were measured, and disease incidence and severity were assessed visually for the radicle only. Disease incidence was calculated as the percentage of emerged seedlings in each cup with lesions on the radicle. Severity was scored on 0 -to-5 scale based on the mean estimated area of each radicle showing lesions, where $0=$ long and healthy roots with no lesions and $1=1$ to $10,2=11$ to $25,3=26$ to $50,4=51$ to 75 , and $5=76$ to $100 \%$ of roots covered with lesions.

Pathogen isolation. To identify which pathogens were associated with corn seedling disease, symptomatic root tissues were rinsed with sterile distilled water and a section of necrotic tissue (2 to $3 \mathrm{~mm}$ in length) was cut from each plant and pressed on sterile paper towel to remove excess water. Although root tissues of the control treatment were asymptomatic, one section of root tissue from each plant was also plated. The tissue pieces were placed underneath an agar medium. For isolation of oomycetes such as Pythium spp., corn meal agar containing pimaricin $(5 \mu \mathrm{g} / \mathrm{ml})$, ampicillin $(250 \mu \mathrm{g} / \mathrm{ml})$, rifampicin $(10 \mu \mathrm{g} / \mathrm{ml})$, pentachloronitrobenzene $(50 \mu \mathrm{g} / \mathrm{ml})$, and benomyl $(10 \mu \mathrm{g} / \mathrm{ml})$ (PARP+B medium) was used (Matthiesen et al. 2016). For isolation of fungi such as Fusarium spp. and Rhizoctonia spp., a water agar medium containing streptomycin $(300 \mathrm{mg} / \mathrm{liter})$ and metalaxyl (96.6\%, $14.2 \mathrm{mg} / \mathrm{liter}$ ) was used (Bakker et al. 2016; Vincelli and Beaupré 1989; Windham and Lucas 1987). Plates were incubated at room temperature for 2 to 3 days in the dark.

Colonies with coenocytic hyphae on PARP+B were transferred to dilute V8 juice media containing neomycin sulfate $(50 \mu \mathrm{g} / \mathrm{ml})$ and chloramphenicol $(10 \mu \mathrm{g} / \mathrm{ml})$, while colonies on water agar were transferred to potato dextrose agar. Putative pathogen isolates were identified to genus using keys based on morphological characteristics (Leslie and Summerell 2006; Middleton 1943; van der Plaats-Niterink 1981; Waterhouse 1967). The incidence of infection by Pythium, Fusarium, or Rhizoctonia spp. was determined as the percentage of seedlings in a cup from which each genus was recovered.

Field study. A field trial was established in each year during 2014 and 2015 at the Iowa State University Boyd Farm in Boone County in fields with a history of corn-soybean rotation. The soils at the field site are Nicollet clay loam (fine loamy, mixed, superactive, mesic Aquic Hapludolls) and Clarion loam (fine loamy, mixed, superactive, mesic Typic Hapludolls). Each plot was an experimental unit, had five rows with 76-cm interrow spacing, and was $18.3 \mathrm{~m}$ long. Treatments consisted of variations in the timing of termination of a rye cover crop relative to corn planting (a no-rye control plus five herbicide application dates for rye cover crop termination, as detailed below). The experiment was laid out in a randomized complete block design with six replications.

A cover crop was established by broadcast seeding of Elbon rye seed on the soil surface following soybean harvest in the fall (19 October 2013 and 21 September 2014) at a rate of $3.125 \times 10^{6}$ seeds/ha. Seed were shallowly incorporated with a rolling stalk chopper (Buffalo Manufacturing Co.). In the spring, the rye was terminated with a glyphosate application of $1.12 \mathrm{~kg}$ a.i./ha using a homemade dry boom sprayer with centrifugal pump. Water volume was 150 liter/ha and boom speed was $8 \mathrm{~km} / \mathrm{h}$ with Tee Jet 8004 flat-fan stainless steel nozzles. The no-rye control plots were also sprayed with glyphosate 3 days before corn planting (DBP) for consistency of exposure to glyphosate and to manage weeds, even though very few winter 
annual weeds were present. Time intervals between rye termination and corn planting varied slightly between the 2 years of the study, due to the influence of weather on field operations. In 2014, herbicide was applied to the rye cover crop 25, 14, 10, or 3 DBP or 1 day after corn planting (DAP). In 2015, herbicide was applied to the rye cover crop $25,17,8$, or 3 DBP or 2 DAP.

Rye shoot biomass was determined by clipping plants close to the soil surface from within a rectangular frame $(0.76 \mathrm{~m}$ wide by $0.50 \mathrm{~m}$ long) placed at two random locations in the interrows on either side of the center row of each plot. Collected biomass was oven dried at $60^{\circ} \mathrm{C}$ and weighed. Samples were finely ground and analyzed for $\mathrm{N}$ content using the dry combustion-gas chromatography method (Schepers et al. 1989) with an EA1112 Flash NC Elemental analyzer (Thermo Electron Corp.). In 2014, rye shoot biomass from the earliest termination date (25 DBP) was not sampled because the plants were very small when terminated.

Seed of the glyphosate-resistant corn hybrid P1151R (DuPontPioneer Hybrid International) were treated with the same fungicide combination used in the growth-chamber study. Corn was planted at a rate of 88,960 seeds/ha (17 May 2014 and 1 May 2015) without preplant tillage in 0.76-m rows using a five-row no-till planter. Average monthly air temperatures and precipitation were obtained from the weather station located approximately $2 \mathrm{~km}$ from the experimental site (Iowa Environmental Mesonet 2015). Soil temperatures from the experimental plots were not monitored in 2014. However, in 2015, the soil temperature at the 5-cm depth was monitored in one plot each for the no-rye, rye terminated $25 \mathrm{DBP}$, and rye terminated 3-DBP treatments.

No fertilizer was applied before planting or during planting to avoid possible effects on soil pathogens in or near the seed furrow. A post-planting side-dress application of $\mathrm{N}$ fertilizer as liquid ureaammonium nitrate was applied next to the corn rows at a rate of $201 \mathrm{~kg} / \mathrm{ha}$ on 3 June 2014 and on 2 June 2015, which was 17 and 32 DAP, respectively.

Seedling growth and disease assessments. Six corn seedlings, three each from two rows of each plot, were arbitrarily sampled to evaluate plant growth and disease incidence. Corn plants were dug out using a spade and the soil was carefully removed with water to preserve as much of the seedling root system as possible. In 2014, seedlings were sampled at the V4 to V5 development stage (17 to 18 June 2014) (Abendroth et al. 2011), whereas in 2015, seedlings were sampled at development stage V2 to V3 (1 to 2 June 2015). When plants were sampled in 2014, it was difficult to dig deep enough to prevent the radicle and longer seminal roots from breaking off; consequently, it was difficult to measure radicle length and evaluate root disease incidence. Sampling at an earlier growth stage in 2015 enabled better recovery of intact seedling root systems, facilitating more accurate evaluation of the radicle and seminal root tissues. Moreover, in 2014, corn seedling radicles and seminal roots were extensively rotted among all treatments compared with the nodal root tissues and the mesocotyl. An earlier sampling time was chosen in 2015 to permit better differentiation among treatments. Measurements included shoot height, radicle length, shoot dry weight, root rot incidence, and root rot severity. Shoot height was measured from the base of the plant to the tip of the longest extended leaf. Disease incidence was estimated based on the presence or absence of lesions observed on the root tissue (i.e., radicle, seminal, and nodal roots) and the mesocotyl of the six sampled plants. Disease severity was assessed using 0-to-5 scales, as described above. In 2014, disease severity was not scored. In 2015, disease severities were assessed for each of the three root tissue types (i.e., radicle, seminal, and nodal roots) as well as for the mesocotyl.

Pathogen isolations, identification, and density in corn roots. In both the 2014 and 2015 trials, isolations for Pythium, Fusarium, and Rhizoctonia spp. associated with the radicle were done for each of the six plants sampled from each plot whether or not lesions were present following the protocol explained above. The incidence of infection by each genus was determined as the percentage of seedlings from which each genus was recovered.
In 2015, we also collected marker gene sequence information to allow for more precise identification of pathogen isolates recovered from corn radicles. Identification of representative isolates of $\mathrm{Fusa}$ rium strains to the species level was done by amplification of the translation elongation factor 1- $\alpha$ (TEF) marker gene using the method of Geiser et al. (2004). For Pythium strains, the cytochrome C oxidase subunit I (COI) marker gene was amplified using the method of Robideau et al. (2011). Resulting amplicons were purified using either a spin column or magnetic bead clean-up method, and were submitted for Sanger sequencing at the Iowa State University DNA Facility. Sequence chromatographs were manually trimmed. Fusarium spp. TEF gene sequences were matched against entries in the Fusarium-ID database (Geiser et al. 2004). Pythium spp. COI gene sequences were compared with those provided by Robideau et al. (2011).

The density of Pythium spp. present in corn seedling tissue was measured using quantitative polymerase chain reaction (qPCR). Sections of mesocotyl and of radicle $(2 \mathrm{~cm}$ in length) were collected from each corn seedling regardless of symptomology. Tissue was bulked from three plants, leaving two subsamples per plot. For mesocotyls, two subsamples were processed per plot and final data were averaged before statistical analyses. For radicles, a mistake during DNA extraction left only one subsample per plot. Tissue samples were freeze dried and pulverized by beating with a tungsten-carbide bead ( $3 \mathrm{~mm}$ in diameter; Qiagen) on a MiniBeadbeater (Biospec Products). DNA was extracted using the DNeasy Plant Mini Kit (Qiagen), according to the manufacturer's directions.

For the specific detection of Pythium spp. within corn tissue samples, we developed hydrolysis probes based on the work of Tambong et al. (2006), who identified and validated oligonucleotides for diagnostic specificity across a test panel of over 100 Pythium spp. Rather than aiming for species-level specificity, we chose oligonucleotides that were shared among members of a given clade or group of closely related Pythium spp. (Robideau et al. 2011). Probe arG190mod (FAM-AAACTTTCGTTCTCGGA-MGB-NFQ) has specificity for members of Pythium clade B, while probe IrSyl123mod (VICACACACAACAAATAACGA-MGB·NFQ) has specificity for members of Pythium clade F. The target for both of these probes is found within the amplicon generated by the same primer set (internal transcribed spacer [ITS]6 and ITS7) (Cooke et al. 2000) which is selective for oomycetes.

qPCR was run on a CFX96 thermocycler and detection system (Bio-Rad). The reaction volume was $20 \mu \mathrm{l}$, consisting of TaqMan Environmental Master Mix 2.0 (Life Technologies), ITS6 and ITS7 primers at $500 \mathrm{nM}$ final concentrations, and a hydrolysis probe (Life Technologies) at $225 \mathrm{nM}$ final concentration. The thermocycler program consisted of $10 \mathrm{~min}$ at $95^{\circ} \mathrm{C}$, followed by 40 cycles of denaturing for $10 \mathrm{~s}$ at $95^{\circ} \mathrm{C}$, annealing and extension for $1 \mathrm{~min} 20 \mathrm{~s}$, and plate read. The annealing temperature was $60^{\circ} \mathrm{C}$ for the clade B assay and $61.5^{\circ} \mathrm{C}$ for the clade $\mathrm{F}$ assay. To be able to express pathogen DNA abundance relative to host plant DNA abundance, thus minimizing error associated with variation in DNA extraction efficiency, the corn tua4 gene was quantified using the assay of Mideros et al. (2009).

Technical triplicates were run for all samples and standards. Each qPCR run included no-template controls and a standard curve of synthesized DNA (Invitrogen) spanning six orders of magnitude in template DNA copy number. Across qPCR runs, the standard curves always produced an $R^{2}>0.99$, and calculated PCR efficiencies were in the range of 93 to $106 \%$. Nondetects were assigned a small nonzero value, defined as half of the calculated DNA content at a cycle threshold of 40. Measured pathogen densities in corn tissue were expressed as pathogen ITS gene copies per million copies of the corn tua4 gene, then $\log _{10}$ transformed.

Agronomic assessments. At physiological maturity, the number of plants, ears, and barren plants from the entire center row of each plot was recorded. Corn yield data were collected from the center three rows of each five-row plot on 30 October 2014 and 19 October 2015. A modified combine (Colvin1990) with an internally mounted weigh tank and grain moisture meter was used to harvest 
and measure grain yield. Grain moisture was adjusted to water at $0.155 \mathrm{~g} / \mathrm{kg}$.

Data analysis. Data were analyzed using SAS (version 9.3; SAS Institute Inc.). Analysis of variance was performed using Proc GLIMMIX for all variables (i.e., plant emergence, shoot height, radicle length, root rot incidence, root rot severity, pathogen incidence, plant stand, ears, number of barren plants, grain moisture, and grain yield). Count data, disease incidence, and disease severity were analyzed using Proc GLIMMIX, as described by Madden et al. (2002). Time intervals between rye termination and corn planting dates were treated as fixed factors and replication as a random factor. If the main effect of treatment was significant, then treatment means were compared using Fisher's least significant difference at $P=0.05$. The interactions between runs and treatments were significant for some of the parameters measured in our controlled-environment studies; thus, results are presented separately for each run. Linear regression analysis was performed to establish the relationship between the time interval between rye cover crop termination and corn planting and shoot weight using PROC REG on SAS.

\section{Results}

Controlled-environment experiment. Seedling emergence. Seedling emergence was significantly affected by the time interval between rye termination and corn planting $(P<0.05$; Table 1$)$ in both runs. Short intervals of 3 days between rye termination and corn planting had lower emergence (65\% in both runs) compared with the no-rye control in run 1 and the 21-DBP and 1-DAP treatments in run 2 . In run 1 , termination intervals of 7 days or more did not significantly affect emergence. In run 2 , however, emergence also was reduced with a 14-day interval between termination and planting but not with the 7- or 21-day intervals. Interestingly, emergence was not negatively affected when rye was terminated 1 DAP.

Shoot height. In general, shorter time intervals between rye termination and corn planting reduced seedling shoot height $(P<0.01$; Table 1). In run 1, shoot height was shortest when the interval was 3 or 7 DBP. These treatments were significantly shorter than the 1-DAP and 14-DBP treatments but were not different from the norye control or the 21-DBP treatment. In run 2, shoot height was reduced in all treatments when the termination interval was 14 days or less. Similar to the corn emergence data, corn shoot height was not negatively affected when corn was planted 1 day after rye termination.

Table 1. Effect of the time interval between rye termination and corn planting on corn seedling growth at V2 to V3 in a controlled environment ${ }^{\mathrm{x}}$

\begin{tabular}{lcccc}
\hline Treatments $^{\mathbf{y}}$ & $\begin{array}{c}\text { Emergence } \\
(\boldsymbol{\%})\end{array}$ & $\begin{array}{c}\text { Shoot } \\
\text { height }(\mathbf{c m})^{\mathbf{z}}\end{array}$ & $\begin{array}{c}\text { Shoot dry } \\
\text { weight }(\mathbf{g})\end{array}$ & $\begin{array}{c}\text { Radicle } \\
\text { length }(\mathbf{c m})\end{array}$ \\
\hline Run 1 & & & & \\
No rye, control & $95 \mathrm{a}$ & $11.2 \mathrm{~cd}$ & $0.35 \mathrm{bc}$ & $9.5 \mathrm{bc}$ \\
Rye, 21 DBP & $90 \mathrm{a}$ & $13.0 \mathrm{bc}$ & $0.35 \mathrm{bc}$ & $10.1 \mathrm{abc}$ \\
Rye, 14 DBP & $85 \mathrm{a}$ & $15.1 \mathrm{ab}$ & $0.39 \mathrm{~b}$ & $11.3 \mathrm{a}$ \\
Rye, 7 DBP & $80 \mathrm{ab}$ & $12.5 \mathrm{c}$ & $0.35 \mathrm{bc}$ & $10.2 \mathrm{ab}$ \\
Rye, 3 DBP & $65 \mathrm{~b}$ & $9.8 \mathrm{~d}$ & $0.21 \mathrm{c}$ & $8.4 \mathrm{~cd}$ \\
Rye, 1 DAP & $100 \mathrm{a}$ & $16.3 \mathrm{a}$ & $0.65 \mathrm{a}$ & $6.8 \mathrm{~d}$ \\
$P>F$ & 0.04 & $<0.01$ & $<0.01$ & $<0.01$ \\
Run 2 & & & & \\
No rye, control & $85 \mathrm{ab}$ & $12.3 \mathrm{a}$ & $0.27 \mathrm{a}$ & $11.2 \mathrm{ab}$ \\
Rye, 21 DBP & $90 \mathrm{a}$ & $12.8 \mathrm{a}$ & $0.25 \mathrm{ab}$ & $13.1 \mathrm{a}$ \\
Rye, 14 DBP & $65 \mathrm{~b}$ & $8.3 \mathrm{~b}$ & $0.11 \mathrm{c}$ & $7.1 \mathrm{~b}$ \\
Rye, 7 DBP & $85 \mathrm{ab}$ & $10.3 \mathrm{ab}$ & $0.23 \mathrm{ab}$ & $5.0 \mathrm{~b}$ \\
Rye, 3 DBP & $65 \mathrm{~b}$ & $8.6 \mathrm{~b}$ & $0.14 \mathrm{bc}$ & $3.9 \mathrm{~b}$ \\
Rye, 1 DAP & $95 \mathrm{a}$ & $12.3 \mathrm{a}$ & $0.33 \mathrm{a}$ & $7.0 \mathrm{~b}$ \\
$P>F$ & $<0.02$ & $<0.01$ & $<0.01$ & $<0.01$ \\
\hline
\end{tabular}

${ }^{x}$ Means followed by the same letter within a column and run are not significantly different at $P$ value 0.05 using Fisher's protected least significant difference.

y Treatments: In the control, corn was planted without rye. Rye was terminated $21,14,7$, or 3 days before planting (DBP) or 1 day after planting (DAP) corn.

${ }^{\mathrm{z}}$ Corn shoot height was measured from ground level to the extended leaf.
Shoot dry weight. An effect of termination-time interval was detected on corn shoot dry weight in both runs $(P<0.01$; Table 1$)$. In run 1 , average corn seedling shoot weight was reduced in the 3-DBP treatment compared with the 14-DBP and 1-DAP treatments, although this was not significantly different from the no-rye control. Similarly, in run 2, shoot weight was reduced in the 3- and 14-DBP treatments, and these treatments were different from the no-rye control. Shoot weight was greatest in the 1-DAP treatment in both runs.

Radicle length. Radicle length was significantly affected by the number of days between rye termination and corn planting $(P<$ 0.01 ; Table 1$)$. The greatest reduction in radicle length was observed when the interval was 3 days or less in run 1 and 14 days or less in run 2 . In contrast to the aboveground measures of corn seedling growth, the 1-DAP treatment resulted in shortened radicle root length.

Root disease. Dark black or brown necrotic lesions were observed on the corn seedling radicles, often near the tip. Lesions were rarely observed on the seminal and nodal roots or the mesocotyl. Consequently, disease incidence and severity data are presented only for the radicle.

In general, radicle root rot incidence was greater in the rye treatments compared with the no-rye control $(P<0.01$, Table 2$)$. In run 1 , incidence was greater in all treatments terminated 14 DBP or less whereas, in run 2 , incidence was greater in all rye treatments.

Radicle root rot severity also was affected significantly by the time interval between rye termination and corn planting $(P<0.01$; Table 2). Rot was less severe or absent in the no-rye control, while severity in the rye treatments ranged from 0.1 to 1.3 in run 1 and from 1.1 to 2.4 in run 2 . Greater rot severity was generally observed in the 3 - and 7-DBP treatments and the 1-DAP treatments in both runs compared with treatments with longer time intervals.

Table 2. Effect of the time interval between rye termination and corn planting on the radicle disease incidence and severity and the incidence of Pythium and Fusarium spp. recovered at the V2 to V3 corn growth stage in a controlled environment

\begin{tabular}{lcccc}
\hline & $\begin{array}{c}\text { Radicle root } \\
\text { rot incidence } \\
(\boldsymbol{\%})^{\mathbf{w}}\end{array}$ & $\begin{array}{c}\text { Radicle root } \\
\text { rot severity } \\
(\mathbf{0 - 5})^{\mathbf{x}}\end{array}$ & $\begin{array}{c}\text { Pythium } \\
\text { incidence } \\
(\boldsymbol{\%})^{\mathbf{y}}\end{array}$ & $\begin{array}{c}\text { Fusarium } \\
\text { incidence } \\
(\boldsymbol{\%})^{\mathbf{z}}\end{array}$ \\
\hline Run 1 & & & & \\
No rye, control & $0 \mathrm{~b}$ & $0.0 \mathrm{~b}$ & $0 \mathrm{~b}$ & $21 \mathrm{bc}$ \\
Rye, 21 DBP & $10 \mathrm{~b}$ & $0.1 \mathrm{~b}$ & $17 \mathrm{ab}$ & $15 \mathrm{c}$ \\
Rye, 14 DBP & $65 \mathrm{a}$ & $0.7 \mathrm{a}$ & $25 \mathrm{ab}$ & $65 \mathrm{abc}$ \\
Rye, 7 DBP & $60 \mathrm{a}$ & $0.9 \mathrm{a}$ & $0 \mathrm{~b}$ & $80 \mathrm{a}$ \\
Rye, 3 DBP & $75 \mathrm{a}$ & $1.0 \mathrm{a}$ & $31 \mathrm{a}$ & $67 \mathrm{ab}$ \\
Rye, 1 DAP & $95 \mathrm{a}$ & $1.3 \mathrm{a}$ & $50 \mathrm{a}$ & $80 \mathrm{a}$ \\
$P>F$ & $<0.01$ & $<0.01$ & 0.01 & 0.01 \\
Run 2 & & & & \\
No rye, control & $24 \mathrm{c}$ & $0.2 \mathrm{~d}$ & $0 \mathrm{c}$ & $75 \mathrm{ab}$ \\
Rye, 21 DBP & $77 \mathrm{~b}$ & $1.1 \mathrm{c}$ & $11 \mathrm{bc}$ & $58 \mathrm{~b}$ \\
Rye, 14 DBP & $94 \mathrm{ab}$ & $1.5 \mathrm{bc}$ & $13 \mathrm{bc}$ & $31 \mathrm{~b}$ \\
Rye, 7 DBP & $100 \mathrm{a}$ & $2.3 \mathrm{ab}$ & $59 \mathrm{a}$ & $95 \mathrm{a}$ \\
Rye, 3 DBP & $100 \mathrm{a}$ & $2.4 \mathrm{a}$ & $21 \mathrm{abc}$ & $67 \mathrm{ab}$ \\
Rye, 1 DAP & $100 \mathrm{a}$ & $1.5 \mathrm{abc}$ & $31 \mathrm{ab}$ & $48 \mathrm{~b}$ \\
$P>F$ & $<0.01$ & $<0.01$ & 0.05 & 0.03 \\
\hline
\end{tabular}

u Means followed by the same letter within a column and run are not significantly different at $P$ value 0.05 using Fisher's protected least significant difference.

v Treatments: In the control, corn was planted without rye. Rye was terminated $21,14,7$, or 3 days before planting (DBP) or 1 day after planting (DAP) corn.

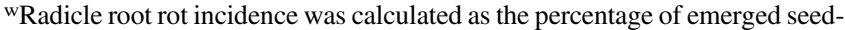
lings with lesions on the radicle.

${ }^{x}$ Root rot severity was scored on a 0-to-5 scale based on the mean estimated area of each radicle showing lesions, where $0=$ long and healthy roots with no lesions and $1=1$ to $10,2=11$ to $25,3=26$ to $50,4=51$ to 75 , and $5=76$ to $100 \%$ of roots covered with lesions.

${ }^{y}$ Pythium incidence was determined as the percentage of plants from which Pythium spp. were isolated.

${ }^{\mathrm{z}}$ Fusarium incidence was determined as the percentage of plants from which Fusarium spp. were isolated. 
Root-rot pathogens. Pythium and Fusarium spp. were recovered from corn seedling radicle tissues plated on semiselective media. Rhizoctonia spp. were not recovered in this experiment. In general, treatments with shorter time intervals between rye termination and corn planting tended to have a greater incidence of Pythium spp. than the control or treatments with longer time intervals $(P<0.05$; Table 2). Similarly, in run 1, incidence of Fusarium spp. was greater in the shorter time-interval treatments than in the 21-DBP and control treatments. In run 2, however, the incidence of Fusarium spp. recovered from the rye treatments was not different from the no-rye control.

Field experiment. Weather conditions. Average monthly air temperatures and precipitation varied in each year of the study (Fig. 1). It was considerably warmer in the second year of the study from December 2014 through March 2015 and slightly warmer March 2015 to May 2015 compared with the same periods in the previous year. More precipitation occurred February through April 2014 than February through April 2015. The corn early grain fill period (July and August) was wetter in 2015 than in 2014. For the 14-DAP period, the average air temperature was $19.0^{\circ} \mathrm{C}$ in 2014 and $16.3^{\circ} \mathrm{C}$ in 2015 , with 65.4 and $49.0 \mathrm{~mm}$ of precipitation in 2014 and 2015, respectively (Iowa Environmental Mesonet 2015).

Rye cover crop biomass and shoot $N$. Rye dry shoot biomass was considerably lower in 2014 compared with 2015 (Fig. 2). The regression models showed a decrease in rye shoot dry weight as termination-time interval increased $\left(2014: R^{2}=0.743, P<0.0001\right.$; 2015: $\left.R^{2}=0.775, P<0.0001\right)$. Mean biomass value was 0.24 to 1.06 and 1.35 to $4.58 \mathrm{Mg} / \mathrm{ha}$ in 2014 and 2015, respectively. In 2014 , cover crop shoot $\mathrm{N}$ concentrations were 2.1 to $2.9 \mathrm{~g} / \mathrm{kg}$. Rye shoots terminated $14 \mathrm{DBP}$ accumulated $\mathrm{N}$ at $7.7 \mathrm{~kg} / \mathrm{ha}$, whereas rye terminated 1 DAP accumulated $\mathrm{N}$ at $27.9 \mathrm{~kg} / \mathrm{ha}$. In 2015, cover crop shoot $\mathrm{N}$ concentrations and $\mathrm{N}$ accumulation ranged from 1.3 and $60.2 \mathrm{~kg} / \mathrm{ha}$, respectively, at 2 DAP to 2.5 and $33.3 \mathrm{~kg} / \mathrm{ha}$, respectively, at 25 DBP. A shorter termination-planting interval corresponded to more days for rye growth; thus, rye biomass production and $\mathrm{N}$ uptake was higher for treatments in which herbicide was applied closer to the time of corn planting. Rye cover crop shoots on the soil surface after termination can reduce soil temperatures because of insulation and reflection of solar radiation (Swan et al. 1996). In 2015, May daily average soil temperature at the 5-cm depth of representative plots with and without rye was $17.3^{\circ} \mathrm{C}$ (no-rye control), $17.0^{\circ} \mathrm{C}(21 \mathrm{DBP})$, and $16.3^{\circ} \mathrm{C}(3 \mathrm{DBP})$.

Corn seedling growth parameters. Corn shoot height was affected by the number of days between rye termination and corn planting $(P<0.01$; Table 3) in both the 2014 and 2015 trials. In general, shorter time intervals between rye termination and corn planting reduced corn seedling shoot height. Average shoot height of corn was shortest when rye was terminated $3 \mathrm{DBP}$ or $1 \mathrm{DAP}$ in 2014 . When rye was terminated 14 or $10 \mathrm{DBP}$, average shoot height also was reduced compared with the no-rye control. No effect of termination at $25 \mathrm{DBP}$ on shoot height was detected. In 2015, seedlings from 8 and 3 DBP showed the shortest shoot length and were significantly shorter compared with the 17- and 25-DBP termination treatments. Also, the 25and 17-DBP and 2-DAP treatments were significantly shorter than the no-rye control.

Shoot dry weight was affected by the number of days between rye termination and corn planting $(P<0.01$; Table 3$)$ in both 2014 and 2015. Shoot weight generally declined when the termination-planting interval was 10 days or less. Shoot weight was greatest in the no-rye control in both years.

The number of days between rye termination and corn planting did not affect corn seedling radicle length in 2014. However, radicle length was affected significantly in $2015(P<0.01$; Table 3$)$. The greatest reduction in radicle length was measured when the terminationplanting interval was 8 days or less. No effect on radicle root length was observed between no-rye control and 17- or 25-DBP termination treatments.

Corn seedling root disease and infection. Seedling root disease was affected by the number of days between rye termination and corn planting $(P<0.01$; Table 4$)$. In general, some evidence of disease was found on both roots and mesocotyls in both years for all termination-time interval treatments, including the control. Lesions

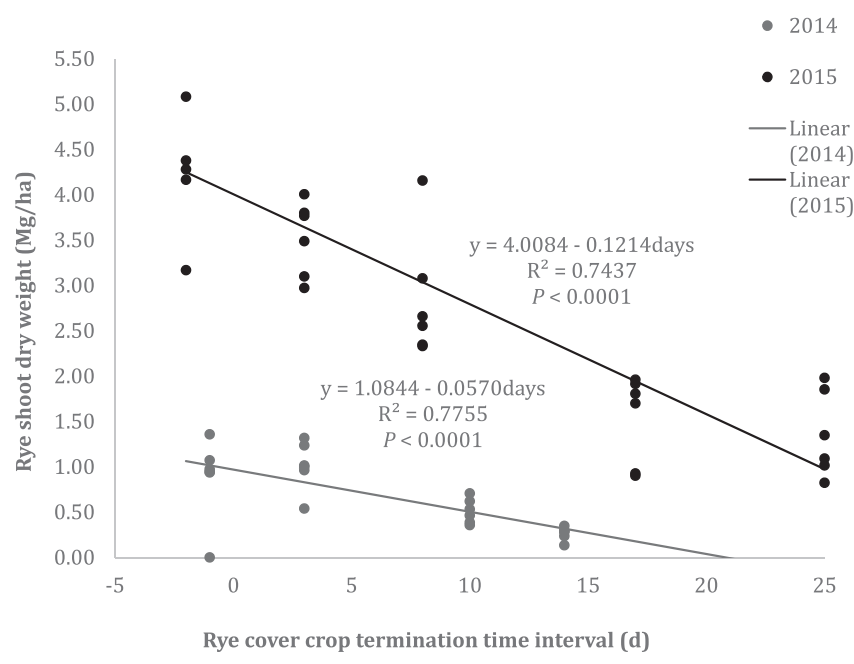

Fig. 2. Relationship between rye cover crop shoot dry weight (Mg/ha) in 2014 and 2015 relative to time interval (days) between rye termination and corn planting date.
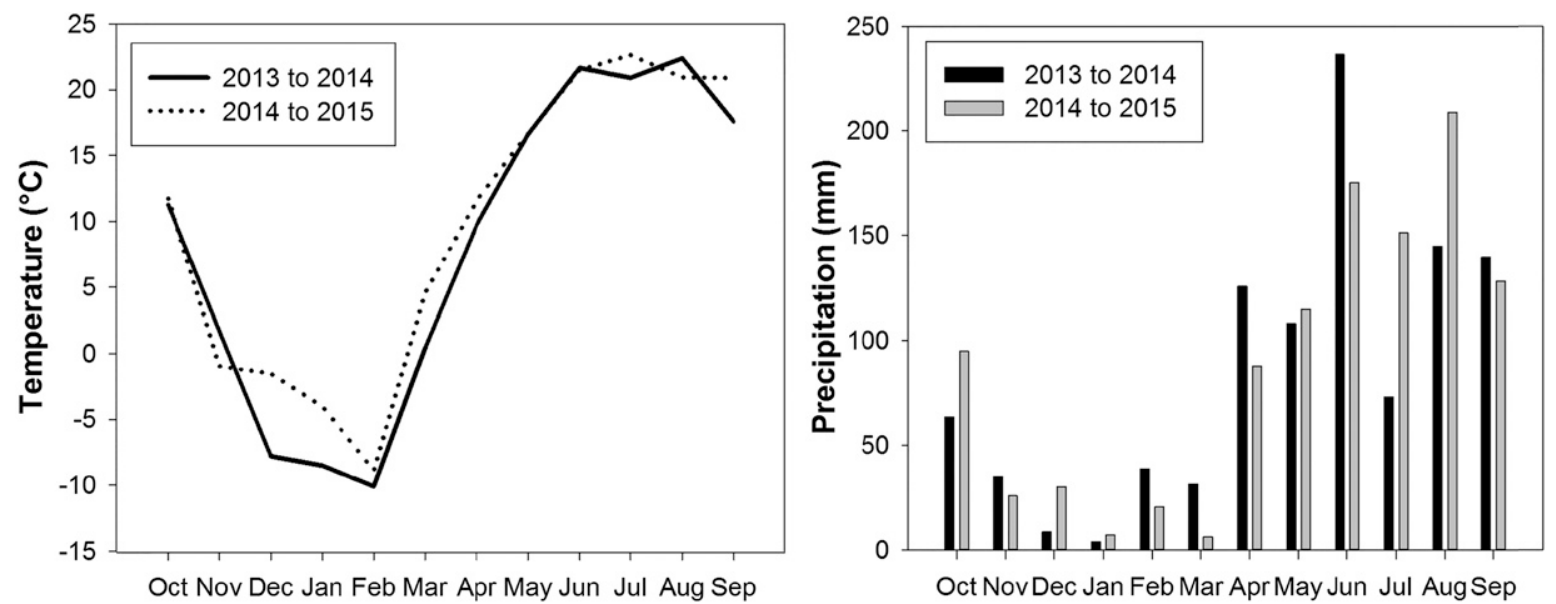

Fig. 1. Average monthly air temperature $\left({ }^{\circ} \mathrm{C}\right)$ and precipitation (millimeters) from March to October obtained from a weather recording station located $2 \mathrm{~km}$ from the experimental site. 
on the radicle were mostly restricted to near the tip whereas, on the other tissues, the lesions were small $(<1 \mathrm{~mm})$ and scattered.

In 2014, radicle and seminal root rot incidence was greatest when the time interval between rye termination and corn planting was 3 days or less. No difference in the incidence of nodal rot was detected. The incidence of mesocotyl rot was greater when rye was

Table 3. Effect of the number of days between rye termination and corn planting on corn seedling growth at growth stage V4 to V5 in 2014 and at V2 to V3 in 2015 Iowa field experiments ${ }^{x}$

\begin{tabular}{lccc}
\hline Treatments $^{\mathbf{y}}$ & $\begin{array}{c}\text { Shoot height } \\
(\mathbf{c m})^{\mathbf{z}}\end{array}$ & $\begin{array}{c}\text { Shoot dry weight } \\
(\mathbf{g})\end{array}$ & $\begin{array}{c}\text { Radicle length } \\
(\mathbf{c m})\end{array}$ \\
\hline 2014 & & & \\
No rye, control & $75.1 \mathrm{a}$ & $52.2 \mathrm{a}$ & 10.4 \\
Rye, 25 DBP & $73.8 \mathrm{ab}$ & $46.3 \mathrm{~b}$ & 9.6 \\
Rye, 14 DBP & $71.7 \mathrm{~b}$ & $45.4 \mathrm{bc}$ & 11.9 \\
Rye, 10 DBP & $71.0 \mathrm{~b}$ & $40.5 \mathrm{c}$ & 10.8 \\
Rye, 3 DBP & $64.3 \mathrm{c}$ & $31.5 \mathrm{~d}$ & 9.3 \\
Rye, 1 DAP & $63.7 \mathrm{c}$ & $30.2 \mathrm{~d}$ & 10.4 \\
$P>F$ & $<0.01$ & $<0.01$ & 0.3 \\
2015 & & & \\
No rye, control & $31.7 \mathrm{a}$ & $5.3 \mathrm{a}$ & $10.2 \mathrm{a}$ \\
Rye, 25 DBP & $27.2 \mathrm{~b}$ & $3.8 \mathrm{~b}$ & $10.0 \mathrm{a}$ \\
Rye, 17 DBP & $26.0 \mathrm{bc}$ & $3.1 \mathrm{c}$ & $10.1 \mathrm{a}$ \\
Rye, 8 DBP & $21.7 \mathrm{~d}$ & $1.5 \mathrm{~d}$ & $6.6 \mathrm{c}$ \\
Rye, 3 DBP & $21.2 \mathrm{~d}$ & $1.3 \mathrm{~d}$ & $7.6 \mathrm{bc}$ \\
Rye, 2 DAP & $24.1 \mathrm{c}$ & $1.5 \mathrm{~d}$ & $8.5 \mathrm{ab}$ \\
$P>F$ & $<0.01$ & $<0.01$ & $<0.01$ \\
\hline
\end{tabular}

${ }^{x}$ Means followed by the same letter within a column and year are not significantly different at $P$ value 0.05 using Fisher's protected least significant difference.

y Treatments: In the control, corn was planted without rye. Rye was terminated $21,14,7$, or 3 days before planting (DBP) or 1 day after planting (DAP) corn.

${ }^{\mathrm{z}}$ Corn shoot height was measured from ground level to the extended leaf. terminated $10 \mathrm{DBP}$ or less compared with the longer termination dates and no-rye control.

In 2015, the incidence of radicle, seminal, and nodal root rot was greatest when corn was planted 8 or less days after terminating rye $(P<0.01$; Table 4$)$. No difference in mesocotyl disease incidence was detected among the treatments.

Radicle root rot severity in 2015 was greatest in the seedlings in the 8-DBP treatment followed by the 3-DBP and 2-DAP treatments. Seminal, nodal, and mesocotyl rot severities were less than 1.0 and did not differ among treatments (data not shown).

Pythium spp. were recovered more frequently from corn seedlings grown in plots that had been planted to rye compared with seedlings sampled from no-rye plots in both years (Table 4). Recovery of Pythium spp. was greatest from the 3-DBP or 1-DAP treatments in 2014 and 8-DBP treatments in 2015. In 2015, marker gene sequence information was collected for 33 Pythium isolates collected from corn root tissue. The species identity of several of the isolates could, at best, be narrowed down to one of two species, because the COI marker gene sequence cannot differentiate all named species of Pythium (Robideau et al. 2011). From within Pythium clade B, we recovered $P$. aristosporum/arrhenomanes (21 isolates) and $P$. folliculosum/torulosum (1 isolate). From within Pythium clade F, we recovered $P$. irregulare ( 2 isolates) and P. sylvaticum ( 9 isolates).

Measuring densities of these two Pythium clades in corn tissue revealed that infection of corn by members of clade $\mathrm{B}$ was responsive to the presence and timing of termination of rye cover crops $(P<$ $0.01)$, whereas infection of corn by members of clade $F$ on the mesocotyl $(P=0.30)$ and radicle $(P=0.46)$ was largely nonresponsive to rye cover crops (Fig. 3).

No effect of the time-interval treatments was detected on the recovery of Fusarium spp. in either year. In 2015, marker gene sequence information was collected for 41 Fusarium isolates collected from corn root tissue. These isolates belonged to five species. The majority of isolates belonged to the $F$. oxysporum species complex (35 isolates), while either 1 or 2 isolates were collected from each of $F$. accuminatum, $F$. armeniacum, $F$. proliferatum, and

Table 4. Effect of the time interval between rye termination and corn planting on corn seedling root disease incidence and severity and the recovery of Pythium and Fusarium spp. from corn seedlings at growth stage V4 to V5 in 2014 and at V2 to V3 in 2015 in field experiments in Iowa ${ }^{\mathrm{r}}$

\begin{tabular}{|c|c|c|c|c|c|c|c|}
\hline Treatments ${ }^{\mathrm{s}}$ & $\begin{array}{c}\text { Radicle RR } \\
\text { incidence }(\%)^{\mathbf{t}}\end{array}$ & $\begin{array}{c}\text { Radicle RR } \\
\text { severity }(0-5)^{\mathbf{u}}\end{array}$ & $\begin{array}{c}\text { Seminal RR } \\
\text { incidence }(\%)^{\mathbf{v}}\end{array}$ & $\begin{array}{c}\text { Nodal RR } \\
\text { incidence }(\%)^{\mathbf{w}}\end{array}$ & $\begin{array}{c}\text { MRR } \\
\text { incidence }(\%)^{x}\end{array}$ & $\begin{array}{c}\text { Pythium } \\
\text { incidence }(\%) \mathrm{y}\end{array}$ & $\begin{array}{c}\text { Fusarium } \\
\text { incidence }(\%)^{z}\end{array}$ \\
\hline \multicolumn{8}{|l|}{2014} \\
\hline No rye, control & $58.3 \mathrm{~d}$ & - & $52.8 \mathrm{c}$ & 44.4 & $2.8 \mathrm{~d}$ & $0.0 \mathrm{c}$ & 41.7 \\
\hline Rye, 25 DBP & $75.0 \mathrm{c}$ & - & $61.1 \mathrm{bc}$ & 13.9 & $11.1 \mathrm{~cd}$ & $8.3 \mathrm{bc}$ & 58.3 \\
\hline Rye, 14 DBP & $72.2 \mathrm{c}$ & - & $61.1 \mathrm{bc}$ & 8.3 & $8.3 \mathrm{~cd}$ & $22.2 \mathrm{~b}$ & 58.3 \\
\hline Rye, 10 DBP & $83.3 \mathrm{bc}$ & - & $69.4 \mathrm{~b}$ & 22.2 & $33.3 \mathrm{~b}$ & $22.2 \mathrm{~b}$ & 63.9 \\
\hline Rye, 3 DBP & $91.7 \mathrm{ab}$ & - & $88.9 \mathrm{a}$ & 36.1 & $25.0 \mathrm{bc}$ & $61.1 \mathrm{a}$ & 68.9 \\
\hline Rye, 1 DAP & $100.0 \mathrm{a}$ & - & $100.0 \mathrm{a}$ & 25.0 & $58.3 \mathrm{a}$ & $75.0 \mathrm{a}$ & 75.0 \\
\hline$P>F$ & $<0.01$ & & $<0.01$ & 0.51 & $<0.01$ & $<0.01$ & 0.06 \\
\hline \multicolumn{8}{|l|}{2015} \\
\hline No rye, control & $8.3 \mathrm{~b}$ & $0.1 \mathrm{~cd}$ & $8.3 \mathrm{~b}$ & $2.8 \mathrm{c}$ & 0.0 & $2.8 \mathrm{c}$ & 61.1 \\
\hline Rye, 25 DBP & $25.0 \mathrm{~b}$ & $0.3 \mathrm{c}$ & $19.4 \mathrm{~b}$ & $11.1 \mathrm{~cd}$ & 2.8 & $19.4 \mathrm{~b}$ & 69.4 \\
\hline Rye, 17 DBP & $25.0 \mathrm{~b}$ & $0.3 \mathrm{c}$ & $5.6 \mathrm{~b}$ & $8.3 \mathrm{~cd}$ & 2.8 & $13.9 \mathrm{bc}$ & 47.2 \\
\hline Rye, 8 DBP & $80.6 \mathrm{a}$ & $1.7 \mathrm{a}$ & $77.8 \mathrm{a}$ & $33.3 \mathrm{~b}$ & 5.6 & $38.9 \mathrm{a}$ & 75.0 \\
\hline Rye, 3 DBP & $80.6 \mathrm{a}$ & $1.2 \mathrm{~b}$ & $80.5 \mathrm{a}$ & $25.0 \mathrm{bc}$ & 8.3 & $19.4 \mathrm{~b}$ & 77.8 \\
\hline Rye, 2 DAP & $83.3 \mathrm{a}$ & $1.0 \mathrm{~b}$ & $80.6 \mathrm{a}$ & $58.3 \mathrm{a}$ & 0.0 & $25.0 \mathrm{~b}$ & 50.0 \\
\hline$P>F$ & $<0.01$ & $<0.01$ & $<0.01$ & $<0.01$ & 0.41 & $<0.01$ & 0.25 \\
\hline
\end{tabular}

${ }^{\mathrm{r}} \mathrm{RR}=$ root rot and MRR = mesocotyl root rot. Means followed by the same letter within a column and year are not significantly different at $P$ value 0.05 using Fisher's protected least significant difference.

s Treatments: In the control, corn was planted without rye. Rye was terminated 25, 14, 10, or 3 days before planting (DBP) or 1 day after planting (DAP) corn in 2014 and $25,17,8$, or 3 DBP or 2 DAP in 2015.

t Radicle RR incidence was calculated as the percentage of emerged seedlings with lesions on the radicle.

u Radicle RR severity was scored on 0-to-5 scale based on the mean estimated area of each radicle showing lesions, where $0=$ long and healthy roots with no lesions and $1=1$ to $10,2=11$ to $25,3=26$ to $50,4=51$ to 75 , and $5=76$ to $100 \%$ of roots covered with lesions.

v Seminal RR incidence was calculated as the percentage of emerged seedlings with lesions on the seminal roots.

${ }^{w}$ Nodal RR incidence was calculated as the percentage of emerged seedlings with lesions on the nodal roots.

${ }^{x}$ MRR incidence was calculated as the percentage of emerged seedlings with lesions on the mesocotyl.

y Pythium incidence was determined as the percentage of plants from which Pythium spp. were isolated.

z Fusarium incidence was determined as the percentage of plants from which Fusarium spp. were isolated. 
F. solani. Rhizoctonia spp. were not recovered from corn seedlings in either year.

Corn yield and agronomic assessments. In 2014, planting corn after rye did not affect yield except in the 1-DAP treatment (Table 5). In 2015 , all rye termination treatments reduced yield compared with the no-rye control, with the 3-DBP and 2-DAP treatments having the lowest yields.

In 2014, treatment effects were detected on the number of ears $(P=$ 0.05 ; Table 5) but not on the total plant population or the number of barren plants. The number of ears was reduced in the 1-DAP treatment compared with all other treatments. In 2015, treatment effects were detected on final stand count, number of ears per hectare, and number of barren plants per hectare. Final plant stand was reduced in all rye treatments, with the greatest reduction occurring in the 2-DAP treatment followed by the 3- and 8-DBP treatments. Similarly, the reduction in the number of ears and the number of barren plants was greatest in the 2-DAP treatment followed by all the other rye treatments for number of ears and by 3- and 8-DBP treatments for number of barren plants.

\section{Discussion}

In Iowa, farmers may be hesitant to grow a rye cover crop prior to planting corn because of occasional reports of reduced yield
(Arbuckle and Roesch-McNally 2015; Johnson et al. 1998; Kaspar and Bakker 2015; Pantoja et al. 2015). The effect of time from termination of the rye cover crop to corn planting on seedling disease, plant growth, and yield of corn was evaluated in the present study. Our results from both the controlled-environment and field experiments showed that shorter time intervals between rye termination and corn planting increased seedling disease and reduced corn emergence, plant population, shoot growth, and grain yield of corn following a rye cover crop compared with corn planted 10 or more days after rye termination or without a cover crop. This would imply that one way to decrease the risk of reduced corn yield following a rye cover crop is to increase the time interval between rye termination and corn planting.

A number of other studies have also reported that increasing the time interval between rye cover crop termination and corn planting decreases the risk of reduced yield (Ball Coelho et al. 2005; Munawar et al. 1990; Raimbult et al. 1991). Although our study does not eliminate other possible explanations for the corn yield benefits of a longer time interval, our field study showed that seedling root infections decreased as the length of the time interval increased and suggests that corn seedling soilborne pathogens may have affected corn population and yield to some extent. Previously, Bakker et al. (2016)

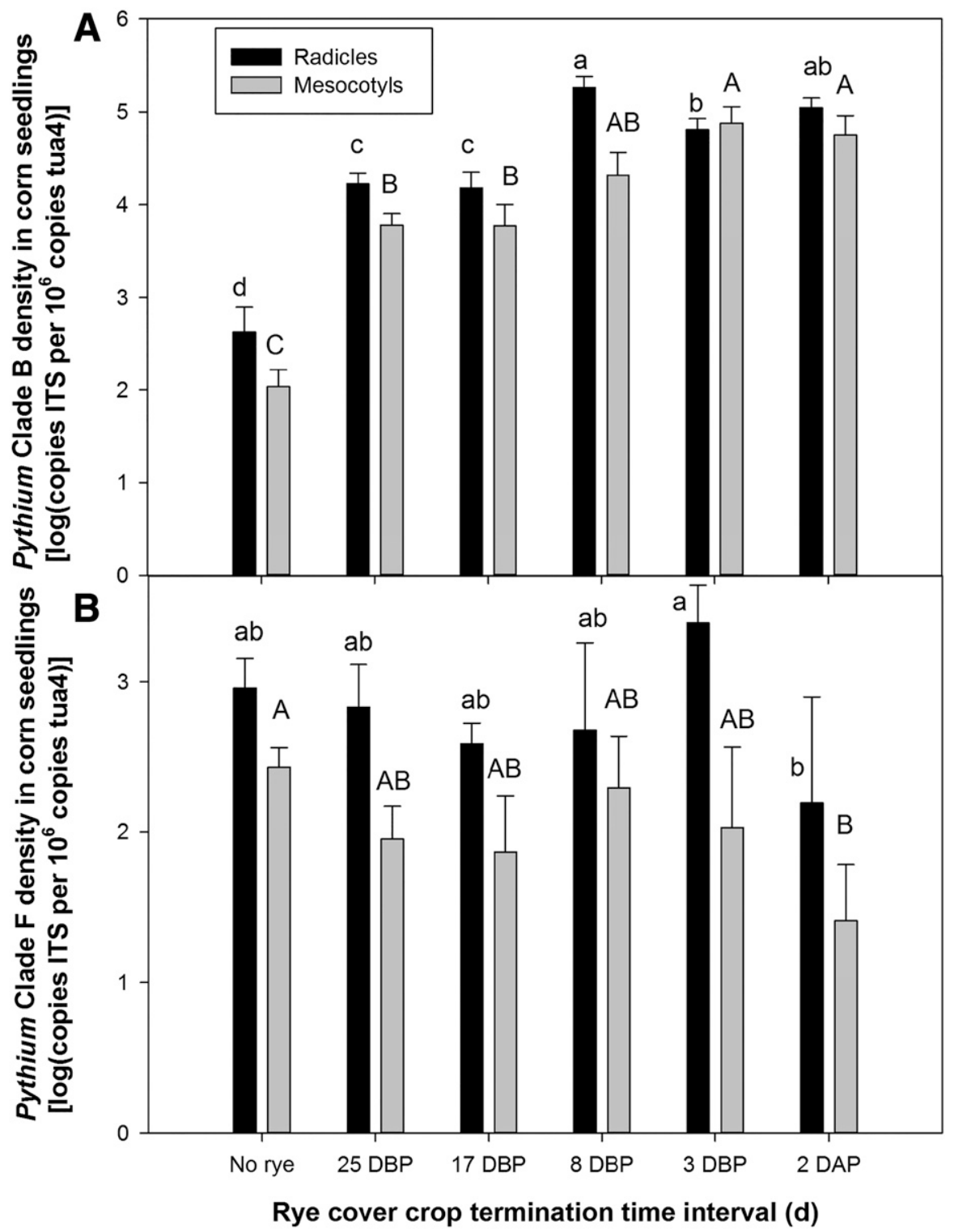

Fig. 3. Density of Pythium spp. belonging to A, clade B and B, clade F in radicles and mesocotyls of corn seedlings in the 2015 field experiment, in relation to rye cover crop termination-time interval (days). Pathogen density (copies of Pythium spp. internal transcribed spacer [ITS] gene) was assessed relative to host plant DNA (copies of corn tua4 gene). $\mathrm{DBP}=$ days before planting and DAP $=$ days after planting. Bars topped with the same letter are not significantly different at $P$ value $=0.05$. 
showed that rye cover crop roots are hosts to pathogens that can infect corn seedling roots and that the densities of some of these pathogens on rye roots increased with time after cover crop termination as the roots decomposed. Additionally, other studies (Dabney et al. 1996; Sharma-Poudyal et al. 2016; Smiley et al. 1992) have also demonstrated with different plant species that increasing the time interval between termination of a cover crop or volunteer plants and planting of the main crop decreased seedling disease and increased growth of the main crop. Thus, it seems likely that increased infection rates by corn seedling root pathogens is a potential cause of corn growth and yield reductions following a rye cover crop. The negative impact of pathogens may diminish with a longer interval of time between cover crop termination and corn planting.

Termination-time interval also affects how long the rye cover crop grows and how much shoot biomass is produced (Fig. 2). In both years of the field study, rye biomass increased as the cover crop was allowed to grow longer before being terminated closer to the time of corn planting. We did not measure cover crop root biomass directly but expect that root biomass productivity is correlated with shoot biomass productivity. We anticipate that, because corn seedling pathogens are associated with rye roots (Bakker et al. 2016), allowing more time for rye root production would lead to greater and more persistent populations of pathogens in the soil.

Additionally, the increased rye biomass of the shorter terminationtime intervals probably affected soil $\mathrm{N}$ availability and soil temperature, which also would have had an impact on corn growth and yield in this study. Kaspar et al. (2012) showed that, over 5 years, a rye cover crop, on average, produced shoot biomass at $1.3 \mathrm{Mg} / \mathrm{ha}$ and took up $\mathrm{N}$ at $41 \mathrm{~kg} / \mathrm{ha}$. In the present study, especially in 2015 and at shorter termination-time intervals, the rye cover crop produced shoot biomass at 1.0 to $4.5 \mathrm{Mg} / \mathrm{ha}$, which contained $\mathrm{N}$ at 20 to $60 \mathrm{~kg} / \mathrm{ha}$. Eventually, a good portion of this $\mathrm{N}$ would be recycled into the soil but, early in the corn growing season, soil $\mathrm{N}$ would be depleted in proportion to the amount of cover crop growth and $\mathrm{N}$ uptake. Because no fertilizer was applied at or before planting in our field trial, early-season corn growth and yield potential most likely was also limited, in part, by $\mathrm{N}$ availability.

Effect of rye cover crop and termination-time interval was more pronounced in 2015 compared with 2014. In 2014, lower grain yield was detected only for the 1-DAP treatment. However, in 2015, a reduction in yield occurred in all rye termination-time interval treatments. This difference in the effect of the termination-time intervals between the 2 years is likely due, in part, to the large difference in rye biomass accumulation in the 2 years. In the 2014 trial, rye was seeded in late fall (19 October 2013) compared with early fall (21 September 2014) for 2015 trial. In addition, average air temperature in March 2015 was warmer $\left(4.6^{\circ} \mathrm{C}\right)$ compared with March 2014 $\left(0.4^{\circ} \mathrm{C}\right)$ (Fig. 1) and this favored spring growth. As a result, the biomass of rye in 2015 was at least fourfold greater than in 2014 for most of the termination-time interval treatments. Additionally, the difference in rye biomass between the earliest and latest termination dates varied; $0.80 \mathrm{Mg} / \mathrm{ha}$ in 2014 and $3.23 \mathrm{Mg} / \mathrm{ha}$ in 2015 . Thus, the uptake of soil $\mathrm{N}$ in rye shoots, rye growth, and $\mathrm{N}$ uptake in response to termination-time intervals, and the probable effect of soil $\mathrm{N}$ depletion and corn root pathogens on corn growth and yield, would have been expected to be greater in 2015 than in 2014.

Greater growth of the rye cover crop at shorter termination-time intervals also leads to greater surface residue cover, which lowers soil temperatures and increases soil moisture (Dam et al. 2005; Swan et al. 1987). Lower soil temperatures directly slow corn germination, growth, and development (Kaspar et al. 1990; Swan et al. 1987, 1996). In northern corn-growing areas, soil temperatures of residue-covered soils are usually well below optimum early in the growing season (Kaspar et al. 1990; Swan et al. 1987, 1996). Cold, wet soils, however, also can increase risk of infection by some soilborne pathogens. Previous studies by Munkvold (1999) showed that cool temperatures favored root rot pathogens that reduced corn seed germination and emergence, and lowered grain yield. Actual yield losses due to soilborne pathogens, however, depend on complex interactions of pathogen levels, weather conditions, soil environments, and other yield-limiting factors. Additionally, colder soil temperatures can slow decomposition of cover crop root residues (Stott et al. 1986; Wildung et al. 1975) and reduce soil $\mathrm{N}$ mineralization (Kladivko and Keeney 1987). Therefore, the reduction in soil temperature caused by greater amounts of rye residues on the soil surface would have provided favorable conditions for pathogen infection of corn seedlings, slowed root decomposition and the subsequent decline in pathogen numbers, reduced $\mathrm{N}$ mineralization, and slowed corn growth, development, and emergence of nodal roots.

One discrepancy between controlled-environment and field experiments was that when rye was terminated 1 DAP corn, no effect of rye was detected on corn seedling shoot growth in the controlledenvironment experiment whereas, in the field experiment, there was a significant reduction. However, radicle lengths in both the controlled-environment and field experiments were reduced when rye was terminated after corn planting. First, the biggest difference between the field and controlled-environment experiments was that, in the controlled-environment study, all rye plants were terminated at

Table 5. Final plant stand, number of ears, number of barren plants, grain moisture, and yield of corn following a rye cover crop that was terminated at different time intervals before and after planting corn in a field trial in Iowa ${ }^{\mathrm{x}}$

\begin{tabular}{|c|c|c|c|c|c|}
\hline Treatments $^{y}$ & Plants/ha & Ears/ha & Barren/ha & Moisture (g/kg) & Yield (Mg/ha) \\
\hline \multicolumn{6}{|l|}{2014} \\
\hline No rye, control & 77,141 & $76,783 \mathrm{a}$ & 359 & 209.7 & $13.9 \mathrm{a}$ \\
\hline Rye, 25 DBP & 77,981 & $77,263 \mathrm{a}$ & 718 & 209.5 & $13.3 \mathrm{a}$ \\
\hline Rye, 14 DBP & 74,508 & $73,553 \mathrm{a}$ & 954 & 207.0 & $13.8 \mathrm{a}$ \\
\hline Rye, 10 DBP & 76,187 & $75,584 \mathrm{a}$ & 598 & 209.6 & $13.7 \mathrm{a}$ \\
\hline Rye, 3 DBP & 74,867 & $73,790 \mathrm{a}$ & 1,076 & 211.6 & $13.5 \mathrm{a}$ \\
\hline Rye, 1 DAP & 68,645 & $67,691 \mathrm{~b}$ & 954 & 209.6 & $12.3 \mathrm{~b}$ \\
\hline$P>F$ & 0.07 & 0.05 & 0.82 & 0.52 & 0.02 \\
\hline \multicolumn{6}{|l|}{2015} \\
\hline No rye, control & $87,188 \mathrm{a}$ & 86,707 a & $474 \mathrm{c}$ & 180.5 & $15.1 \mathrm{a}$ \\
\hline Rye, 25 DBP & $80,249 \mathrm{bc}$ & $79,775 \mathrm{~b}$ & $474 \mathrm{c}$ & 181.1 & $14.1 \mathrm{~b}$ \\
\hline Rye, 17 DBP & 80,012 bc & $79,057 \mathrm{~b}$ & $954 \mathrm{c}$ & 178.5 & $14.0 \mathrm{~b}$ \\
\hline Rye, 8 DBP & $82,645 \mathrm{~b}$ & $80,012 \mathrm{~b}$ & $2,626 \mathrm{~b}$ & 181.1 & $13.5 \mathrm{bc}$ \\
\hline Rye, 3 DBP & $82,760 \mathrm{~b}$ & $80,012 \mathrm{~b}$ & $2,748 \mathrm{~b}$ & 181.7 & $12.9 \mathrm{~cd}$ \\
\hline Rye, 2 DAP & $76,302 \mathrm{c}$ & $71,161 \mathrm{c}$ & 5,138 a & 182.0 & $12.3 \mathrm{~d}$ \\
\hline$P>F$ & 0.01 & $<0.01$ & $<0.01$ & 0.30 & $<0.01$ \\
\hline
\end{tabular}

${ }^{x}$ Means followed by the same letter within a column and year are not significantly different at $P$ value 0.05 using Fisher's protected least significant difference.

y Treatments: In the control, corn was planted without rye. Rye was terminated at 25, 14, 10, or 3 days before planting (DBP) or 1 day after planting (DAP) corn in 2014 and at $25,17,8$, or 3 DBP or 2 DAP in 2015.

${ }^{\mathrm{z}}$ Corn yield data were collected from the center three rows of each plot. 
the same time and had the same amount of growth at that time. Second, the environmental conditions were quite different between the two experiments. In the controlled environment, conditions after planting were kept consistently cold $\left(12^{\circ} \mathrm{C}\right)$, wet, and well-supplied with nutrients. In the field, however, fluctuating soil and air temperatures, wind, and water and nutrient availability may have resulted in greater plant stress than occurred in the controlled environment and, if root function was impeded by infection, this may have limited shoot growth.

Average shoot dry weight of corn seedlings was considerably greater in the 2014 trial compared with the 2015 trial. This difference was attributed mostly to the difference in plant growth stage at sampling time. We observed greater root rot and disease incidence on the radicles and the seminal roots for all treatments in 2014. The radicle and seminal roots are the first roots to emerge relatively soon after germination and their growth slows considerably after V2, when the nodal root system starts to develop (Abendroth et al. 2011). Consequently, these tissues had a longer time to become infected in 2014, even at relatively low levels of inoculum where rye was terminated far in advance of corn planting.

We observed more root rot on the radicle than on the seminal, nodal, and mesocotyl tissues in both the controlled-environment and field studies. Radicle length was significantly shorter due to root rot when rye was terminated within a week of planting. These data suggest that the radicle tissue was more susceptible to infection by cover-crop-borne pathogens. This may be partly because the resistance mechanism in each of these root tissues differs, although we are not aware of data that address this question specifically. In legumes, differences in the susceptibility of the hypocotyl and root tissues to oomycetes pathogens has been reported ( $\mathrm{Li}$ et al. 2015; Schmitthenner 1985; You et al. 2005). Because the radicle emerges first, it has a longer period of exposure to pathogens and more time for symptom development compared with other root tissues. Pathogen densities may also have been higher at the time of radicle emergence compared with later time points as other roots emerged. We speculate that nodal roots are less susceptible to infection because they emerge later, when pathogen densities may be lower and environmental conditions are less favorable for disease. Aspects of nodal root physiology or defense-response systems may also contribute to lower susceptibility in nodal roots compared with the radicle. If seedlings survive until V6, when the nodal roots become the dominant root system of corn plants (Abendroth et al. 2011), then the corn plants may partly overcome the early infection of radicles and seminal roots.

In our study, Pythium and Fusarium spp. were more often recovered from corn seedlings following rye than from corn seedlings following a fallow treatment. This lends further support to the idea that rye cover crops may elevate the risk of corn seedling disease (Bakker et al. 2016). This knowledge of shared pathogens between rye and corn should be considered in management practices. For example, care should be taken to use a termination-time interval that minimizes seedling disease risk, so that the beneficial effects of cover cropping on soil quality can be exploited for improved yields.

The effect of rye on the incidence of Fusarium spp. in corn radicles was not consistent between the controlled-environments studies and the field trial. In the controlled-environment study, the incidence of Fusarium spp. was greater in one of the two runs when corn followed rye at intervals of less than 14 days compared with the no-rye control or a 21-day interval. However, in the second controlled-environment run and both years of the field study, incidence of Fusarium spp. recovered from the corn seedlings was relatively high for all treatments and there were no significant differences among treatments. We speculate that the soil used in the second controlled-environment experiment and at the field site in both years had high background levels of Fusarium spp., and this masked the effect of the rye cover crop or the termination-time interval.

In both the controlled-environment trials and field studies, incidence of Pythium spp. was consistently greater following rye treatments versus a no-rye control. Furthermore, incidence tended to be greater with shorter termination-time intervals. Part of the reason for significant differences among treatments for incidence of Pythium spp. may be the low background levels measured for the no-rye controls in both experiments. This may indicate that Pythium inoculum density in the soil is enhanced by the rye cover crop roots. Additionally, after the rye cover crop is terminated, the rye residue on the soil surface may help to keep the soil wetter and cooler. Many Pythium spp. depend on swimming zoospores to infect their host plant; consequently, free water or close contact and water films on soil aggregates are required for infection to occur. Therefore, soil water and temperature conditions may have been more favorable for Pythium infection in the field studies when rye residues covered the soil surface. Rye residues, however, were removed in the controlled-environment studies; thus, this argument may not apply.

Rhizoctonia spp. were not recovered at all in this study. Rhizoctonia spp. tend to be more active in warm $\left(25\right.$ to $\left.30^{\circ} \mathrm{C}\right)$ soils (Harikrishnan and Yang 2004). Soil temperatures in the 2015 field trial were about 16 to $17^{\circ} \mathrm{C}$. Another possible reason that no Rhizoctonia sp. was recovered may have been the selective media we used in this study. Future studies that evaluate the impact of rye on infection of corn by Rhizoctonia spp. could use more selective media or molecular biology techniques.

Our study demonstrates that termination-time interval of a rye cover crop before planting corn can affect corn growth and yield and that soil pathogens of corn seedlings may be one of the causes of this effect when the conditions are conducive for disease development. In both our controlled-environment and field experiments, shorter time intervals between rye termination and corn planting were favorable for infection of corn seedlings by soilborne pathogens such as Pythium and Fusarium spp., and were detrimental to corn growth and yield. It is clear from other studies that rye cover crops provide many benefits to soil and water quality; however, cover crop management practices should be developed to minimize risks associated with pathogens that can infect both the cover crop and the main crop. To reduce risk of reduced grain yields, we recommend terminating a rye cover crop a minimum of 10 to $14 \mathrm{DBP}$ corn. With further study, however, it may be more effective to base recommendations for cover crop termination on soil temperature and thermal time rather than on days, or on quantity of rye biomass produced. Similarly, precise positioning of rye cover crops, such as planting cover crops in the interrow at a fixed distance from the row position where corn will be planted, could provide an expanded window of time for corn seedling roots to grow before they intercept decomposing rye roots and their resident pathogen communities. Improved understanding and management of cover crop systems will bring us closer to realizing the potential of cover crops to improve and protect soil and water quality in our agroecosystems.

\section{Acknowledgments}

We thank Iowa Nutrient Reduction Research Center and the Leopold Center for funding the project, K. Kohler for establishing and managing the field trial, and Y. Kandel for helping with data analysis and reviewing the manuscript.

\section{Literature Cited}

Abendroth, L. J., Elmore, R. W., Boyer, M. J., and Marlay, S. K. 2011. Corn Growth and Development, PMR 1009. Iowa State University Extension and Outreach, Ames.

Arbuckle, J. G., and Roesch-McNally, G. 2015. Cover crop adoption in Iowa: The role of perceived practice characteristics. J. Soil Water Conserv. 70:418-429.

Bakker, M. G., Acharya, J., Moorman, T. B., Robertson, A. E., and Kaspar, T. C 2016. The potential for cereal rye cover crops to host corn seedling pathogens Phytopathology 106:591-601.

Ball Coelho, B. R., Roy, R. C., and Bruin, A. J. 2005. Long-term effects of latesummer overseeding of winter rye on corn grain yield and nitrogen balance. Can. J. Plant Sci. 85:543-554.

Basche, A. D., Kaspar, T. C., Archontoulis, S. V., Jaynes, D. B., Sauer, T. J., Parkin, T. B., and Miguez, F. E. 2016. Soil water improvements with the long-term use of a winter rye cover crop. Agric. Water Manage. 172:40-50.

Colvin, T. S. 1990. Automated weighing and moisture sampling for a field- plot combine. Appl. Eng. Agric. 6:713-714.

Cooke, D. E. L., Drenth, A., Duncan, J. M., Wagels, G., and Brasier, C. M. 2000 A molecular phylogeny of Phytophthora and related oomycetes. Fungal Genet. Biol. 30:17-32. 
Dabney, S. M., Schreiber, J. D., Rothrock, C. S., and Johnson, J. R. 1996. Cover crops affect sorghum seedling growth. Agron. J. 88:961-970.

Dam, R. F., Mehdi, B. B., Burgess, M. S. E., Madramootoo, C. A., Mehuys, G. R., and Callum, I. R. 2005. Soil bulk density and crop yield under eleven consecutive years of corn with different tillage and residue practices in a sandy loam soil in central Canada. Soil Tillage Res. 84:41-53.

David, M. B., Gentry, L. E., Kovacic, D. A., and Smith, K. M. 1997. Nitrogen balance in and export from an agricultural watershed. J. Environ. Qual. 26: 1038-1048.

Dinnes, D. L., Karlen, D. L., Jaynes, D. B., Kaspar, T. C., Hatfield, J. L., Colvin, T. S., and Cambardella, C. A. 2002. Nitrogen management strategies to reduce nitrate leaching in tile-drained Midwestern soils. Agron. J. 94:153-171.

Duiker, S., and Curran, W. 2005. Rye cover crop management for corn production in the northern Mid-Atlantic region. Agron. J. 97:1413-1418.

Ebelhar, S. A., Frye, W. W., and Blevins, R. L. 1984. Nitrogen from legume cover crops for no-tillage corn. Agron. J. 76:51-55.

Geiser, D. M., Jimenez-Gasco, M. D., Kang, S., Makalowska, I., Veeraraghavan, N., Ward, T. J., Zhang, N., Kuldau, G. A., and O'Donnell, K. 2004. FUSARIUM-ID v. 1.0: A DNA sequence database for identifying Fusarium. Eur. J. Plant Pathol. 110:473-479.

Harikrishnan, R., and Yang, X. B. 2004. Recovery of anastomosis groups of Rhizoctonia solani from different latitudinal positions and influence of temperatures on their growth and survival. Plant Dis. 88:817-823.

Iowa Environmental Mesonet. 2015. NWS COOP Network. Online publication. Iowa State University Department of Agronomy. http://mesonet.agron.iastate. edu/request/coop/fe.phtml

Johnson, T. J., Kaspar, T. C., Kohler, K. A., Corak, S. J., and Logsdon, S. D. 1998. Oat and rye overseeded into soybean as fall cover crops in the upper Midwest. J. Soil Water Conserv. 53:276-279.

Karlen, D. L., and Doran, J. W. 1991. Cover crop management effects on soybean and corn growth and nitrogen dynamics in an on-farm study. Am. J. Altern. Agric. 6:71-82.

Kaspar, T. C., and Bakker, M. G. 2015. Biomass production of 12 winter cereal cover crop cultivars and their effect on subsequent no-till corn yield. J. Soil Water Conserv. 70:353-364

Kaspar, T. C., Erbach, D. C., and Cruse, R. M. 1990. Corn response to seed-row residue removal. Soil Sci. Soc. Am. J. 54:1112-1117.

Kaspar, T. C., Jaynes, D. B., Parkin, T. B., and Moorman, T. B. 2007. Rye cover crop and gamagrass strip effects on $\mathrm{NO}_{3}$ concentration and load in tile drainage. J. Environ. Qual. 36:1503-1511.

Kaspar, T. C., Jaynes, D. B., Parkin, T. B., Moorman, T. B., and Singer, J. W. 2012. Effectiveness of oat and rye cover crops in reducing nitrate losses in drainage water. Agric. Water Manage. 110:25-33.

Kessavalou, A., and Walters, D. T. 1997. Winter rye cover crop following soybean under conservation tillage. Agron. J. 89:68-74.

Kladivko, E. J., and Keeney, D. R. 1987. Soil nitrogen mineralization as affected by water and temperature interactions. Biol. Fertil. Soils 5:248-252.

Leslie, J. F., and Summerell, B. A., eds. 2006. The Fusarium Laboratory Manual, 1st ed. Blackwell Publishing, Ames, IA.

Li, Y. P., You, M. P., Colmer, T. D., and Barbetti, M. J. 2015. Effect of timing and duration of soil saturation on soilborne Pythium diseases of common bean (Phaseolus vulgaris). Plant Dis. 99:112-118.

Madden, L. V., Turechek, W. W., and Nita, M. 2002. Evaluation of generalized linear mixed models for analyzing disease incidence data obtained in designed experiments. Plant Dis. 86:316-325.

Matthiesen, R. L., Ahmad, A. A., and Robertson, A. E. 2016. Temperature affects aggressiveness and fungicide sensitivity of four Pythium spp. that cause soybean and corn damping off in Iowa. Plant Dis. 100:583-591.

Middleton, J. T. 1943. The Taxonomy, Host Range and Geographical Distribution of the Genus Pythium. Published for the Club by Lancaster Press, Lancaster, PA.

Mideros, S. X., Windham, G. L., Williams, W. P., and Nelson, R. J. 2009. Aspergillus flavus biomass in maize estimated by quantitative real-time polymerase chain reaction is strongly correlated with aflatoxin concentration. Plant Dis. 93:1163-1170.

Mitchell, W. H., and Tell, M. R. 1977. Winter-annual cover crops for no-tillage corn production. Agron. J. 69:569-573.

Moore, E. B., Wiedenhoeft, M. H., Kaspar, T. C., and Cambardella, C. A. 2014. Rye cover crop effects on soil quality in no-till corn silage-soybean cropping systems. Soil Sci. Soc. Am. J. 78:968-976.

Munawar, A., Blevins, R. L., Frye, W. W., and Saul, M. R. 1990. Tillage and cover crop management for soil water conservation. Agron. J. 82:773-777.

Munkvold, G. P. 1999. Corn seedling diseases causing problems. Online publication. Iowa State University Integrated Crop Management News 2156. http://lib.dr.iastate.edu/cropnews/2156
Munkvold, G. P., and O'Mara, J. K. 2002. Laboratory and growth chamber evaluation of fungicidal seed treatments for maize seedling blight caused by Fusarium species. Plant Dis. 86:143-150.

NASS. 2014. 2012 Census of Agriculture. Online publication. United States Department of Agriculture National Agriculture Statistics Service. http:// www.agcensus.usda.gov/Publications/2012/\#fullreport

Pantoja, J. L., Woli, K. P., Sawyer, J. E., and Barker, D. W. 2015. Corn nitrogen fertilization requirement and corn-soybean productivity with a rye cover crop. Soil Sci. Soc. Am. J. 79:1482-1495.

Raimbult, B. A., Vyn, T. J., and Tollenaar, M. 1991. Corn response to rye cover crop, tillage methods, and planter options. Agron. J. 83:287-290.

Reddy, K. N., Zablotowicz, R. M., Locke, M. A., and Koger, C. H. 2003. Cover crop, tillage, and herbicide effects on weeds, soil properties, microbial populations, and soybean yield. Weed Sci. 51:987-994.

Robideau, G. P., de Cock, A. W., Coffey, M. D., Voglmayr, H., Brouwer, H., Bala K., Chitty, D. W., Desaulniers, N., Eggertson, Q. A., Gachon, C. M. M., Hu, C., Kupper, F., Rintoul, T. L., Sarhan, E., Verstappen, E. C. P., Zhang, Y., Bonants, P. J. M., Ristaino, J. B., and Levesque, C. A. 2011. DNA barcoding of oomycetes with cytochrome $\mathrm{c}$ oxidase subunit I and internal transcribed spacer. Mol. Ecol. Resour. 11:1002-1011.

Rothrock, C. S., and Kirkpatrick, T. L. 1995. The influence of winter legume cover crops on soilborne plant pathogens and cotton seedling diseases. Plant Dis. 79:167-171.

Schepers, J. S., Francis, D. D., and Thompson, M. T. 1989. Simultaneous determination of total $\mathrm{C}$, total $\mathrm{N}$, and ${ }^{15} \mathrm{~N}$ on soil and plant material. Commun. Soil Sci. Plant Anal. 20:949-959.

Schmitthenner, A. F. 1985. Problems and progress in control of Phytophthora root rot of soybean. Plant Dis. 69:362-368.

Sharma-Poudyal, D., Paulitz, T. C., and du Toit, L. J. 2016. Timing of glyphosate applications to wheat cover crops to reduce onion stunting caused by Rhizoctonia solani. Plant Dis. 100:1474-1481.

Singer, J. W., Nusser, S. M., and Alf, C. J. 2007. Are cover crops being used in the US corn belt? J. Soil Water Conserv. 62:353-358.

Smiley, R. W., Ogg, A. G., and Cook, R. J. 1992. Influence of glyphosate on Rhizoctonia root rot, growth, and yield of barley. Plant Dis. 76:937-942.

Snapp, S. S., Swinton, S. M., Labarta, R., Mutch, D., Black, J. R., Leep, R., Nyiraneza, J., and O'Neil, K. 2005. Evaluating cover crops for benefits, costs and performance within cropping system niches. Agron. J. 97:322-332.

Stott, D. E., Elliott, L. F., Papendick, R. I., and Campbell, G. S. 1986. Low temperature or low water potential effects on the microbial decomposition of wheat residue. Soil Biol. Biochem. 18:577-582.

Swan, J. B., Kaspar, T. C., and Erbach, D. C. 1996. Seed-row residue management for corn establishment in the northern us corn belt. Soil Tillage Res. 40:55-72.

Swan, J. B., Schneider, E. C., Moncrief, J. F., Paulson, W. H., and Peterson, A. E. 1987. Estimating corn growth, yield, and grain moisture from air growing degree days and residue cover. Agron. J. 79:53-60.

Tambong, J. T., de Cock, A. W., Tinker, N. A., and Lévesque, C. A. 2006 Oligonucleotide array for identification and detection of Pythium species. Appl. Environ. Microbiol. 72:2691-2706.

Teasdale, J. R. 1996. Contribution of cover crops to weed management in sustainable agricultural systems. J. Prod. Agric. 9:475-479.

Tollenaar, M., Mihajlovic, M., and Vyn, T. J. 1993. Corn growth following cover crops: Influence of cereal cultivar, cereal removal, and nitrogen rate. Agron J. 85:251-255.

van der Plaats-Niterink, A. J. 1981. Monograph of the genus Pythium. Studies in Mycology, no. 21. Centraalbureau voor Schimmelcultures, Baarn, The Netherlands.

Varco, J. J., Spurlock, S. R., and Sanabria-Garro, O. R. 1999. Profitability and nitrogen rate optimization associated with winter cover management in notillage cotton. J. Prod. Agric. 12:91-95.

Vincelli, P. C., and Beaupré, C. M.-S. 1989. Comparison of media for isolating Rhizoctonia solani from soil. Plant Dis. 73:1014-1017.

Wagger, M. G., and Mengel, D. B. 1993. The role of nonleguminous cover crops in the efficient use of water and nitrogen. Pages 115-127 in: Cropping Strategies for Efficient Use of Water and Nitrogen. W. L. Hargrove, ed. ASA-CSSASSSA, Madison, WI.

Waterhouse, G. M. 1967. Key to Pythium Pringsheim. Mycol. Pap. 109:1-15.

Wildung, R. E., Garland, T. R., and Buschbom, R. L. 1975. The interdependent effects of soil temperature and water content on soil respiration rate and plant root decomposition in arid grassland soils. Soil Biol. Biochem. 7:373-378.

Windham, A. S., and Lucas, L. T. 1987. A qualitative baiting technique for selective isolation of Rhizoctonia zeae from soil. Phytopathology 77:712-714.

You, M. P., Barbetti, M. J., and Nichols, P. G. H. 2005. New sources of resistance identified in Trifolium subterraneum breeding lines and cultivars to root rot caused by Fusarium avenaceum and Pythium irregulare and their relationship to seedling survival. Australas. Plant Pathol. 34:237-244. 